\title{
Synovial fluid as an auxiliary diagnostic tool for different stages of canine visceral leishmaniasis
}

\author{
Mário César Rennó ${ }^{1}$ (D) Amanda Otoni Vasconcellos ${ }^{1}$ Rogerio Rodrigues Santos $^{1}$ \\ Rodrigo Otávio Silveira Silva ${ }^{1 *}$ Rubens Antônio Carneiro ${ }^{1}$ Paulo Ricardo de Oliveira Paes ${ }^{1}$
}

${ }^{1}$ Universidade Federal de Minas Gerais (UFMG), 31.270-901, Belo Horizonte, MG, Brasil. E-mail: rodrigo.otaviosilva@gmail.com. ${ }^{*}$ Corresponding author.

ABSTRACT: Leishmaniasis represents a complex of chronic diseases with a broad geographic distribution and a high significance in public health worldwide. The varied clinical signs in conjunction with the low sensitivity and specificity of canine visceral leishmaniasis (CVL) detection methods make diagnosis of the disease complex. Among the several available laboratory tests, studies have suggested that the detection of parasites in synovial fluid (SF) is a good auxiliary tool in the diagnosis of CVL. However, no study has evaluated the influence of the clinical stage of CVL in the detection of Leishmania sp. in SF. This study aimed to evaluate the detection of Leishmania sp. amastigotes in the SF of dogs at different stages of the disease. The negative control group (G1) comprised 12 dogs that tested negative for CVL. Thirty-six other dogs, tested serologically positive for CVL, were divided into two groups: Group $2(G 2)$, which included animals at stage II of the disease (moderate; $n=18)$, and Group 3 (G3) included animals at stage III of the disease (severe; $n=18)$. The analysis of SF revealed the presence of parasites in six (33.3\%) dogs from $G 2$ and in 16 (88.9\%) dogs from $G 3$ ( $p=0.0437)$. The present research suggested that $S F$ analysis is of high value as a supplementary tool in the diagnosis of CVL. As a new finding, the present study also indicated that this test has a higher sensitivity in animals presenting with more severe stage of the disease.

Key words: Leishmania infantum, zoonosis.

Líquido sinovial como ferramenta diagnóstica auxiliar da leishmaniose visceral canina em diferentes estádios

\begin{abstract}
RESUMO: As leishmanioses representam um complexo de doenças de caráter crônico de alta importância na saúde pública mundial e com distribuição geográfica ampla. A apresentação clínica variada e a baixa sensibilidade e especificidade de alguns métodos para a detecção da doença tornam complexo o diagnóstico da leishmainiose visceral canina ( $L V C)$. Entre os diversos testes laboratóriais disponíveis, estudos tem sugerido que a pesquisa de parasitos no líquido sinovial (LS) pode ser uma ferramenta auxiliar no diagnóstico da LVC. Apesar disso, inexistem estudos avaliando a relação entre o estágio clínico da doença e a detecção de Leishmania sp. no LS. Dessa forma, o presente trabalho teve como objetivo avaliar a detecção de amastigotas de Leishmania sp. no LS de cães acometidos por diferentes estádios da doença. Foram avaliados 48 cães, sendo 12 negativos para LVC (grupo controle negativo, G1) e 36 soropositivos. O grupo 2 (doença moderada, G2) incluiu animais classificados no estádio II da doença, enquanto o grupo 3 (doença grave, G3) abrangeu animais classificados em estádio III. $\mathrm{Na}$ análise do líquido sinovial dos cães, o parasito foi visualizado em seis (33,3\%) cães do G2 e 16 (88,9)\% dos cães de G3 (p=0.0437). O presente trabalho sugere que a análise do LS apresenta alto valor como ferramenta suplementar no diagnóstico da LVC. Em adição, o presente estudo indica, pela primeira vez, que o teste apresenta uma sensibilidade maior em animais que apresentam a forma grave da doença. Palavras-chave: calazar, Leishmania infantum, zoonoses.
\end{abstract}

Canine visceral leishmaniasis (CVL) is a 2 chronic zoonosis caused by intracellular protozoans 3 of the genus Leishmania and can be fatal if left 4 untreated (RIBEIRO et al., 2018). Leishmaniasis is 5 considered one of the most important protozoosis, 6 reported in 98 countries on five continents, with 7 more than $90 \%$ of the estimated 300,000 new cases 8 per year occurring in six countries, including Brazil 9 (WHO, 2010; WHO, 2014).

Dogs are considered the main reservoir of amastigotes in urban areas and act as a source of infection for vectors in the domestic environment (MONTEIRO et al., 2005). Thus, for the control of leishmaniasis in humans, an efficient method for CVL diagnosis in dogs is necessary (VILAS et al., 2014). However, the detection of CVL remains challenging. CVL involves a wide range of clinical signs that vary according to the stage of the disease and are similar to those of several other common canine diseases (NOLI \& SARIDOMICHELAKIS, 2014). Currently, serological methods [including lateral flow tests, indirect immunofluorescence assay (IFAT), 
1 and enzyme-linked immunosorbent assay (ELISA)] 2 are the most common tests used routinely in clinical 3 settings and in the Brazilian CVL official control 4 program. However, several studies have shown that 5 the low sensitivity of these methods has a negative 6 impact on CVL surveillance and control (LOPES et al., 2017; MENDONÇA, et al., 2017).

Alternatively, direct diagnostic tests are known to have a specificity close to $100 \%$ (NOLI \& SARIDOMICHELAKIS, 2014). The parasitological methods are commonly based on the parasite's detectability in blood smears or lymph node, skin, spleen, or bone morrow cytology (ALVAR et al., 2004; NOLI \& SARIDOMICHELAKIS, 2014). However, collection of most of these specimens is not easy, and the sensitivity of these tests can vary from $20 \%$ to 80\% (SARIDOMICHELAKI et al., 2009, SOLANOGALLEGO et al., 2009, SILVA et al., 2014). One interesting alternate option for the direct diagnosis of Leishmania sp. is to investigate the cytology of synovial fluid (SF), which is easy to collect and much less invasive than most other commonly used specimens (NOLI \& SARIDOMICHELAKIS, 2014). Previous studies using SF have demonstrated sensitivities between 23\% and 64\% (SILVA, 2009). However, these studies have evaluated the presence of the parasite in the SF in light of the known clinical stage of the disease, resulting in a lack of clarity as to whether this approach is applicable to the diagnosis of CVL. This study aimed to evaluate the detection of Leishmania sp. amastigotes in the SF of dogs at different stages of the disease in the metropolitan area of Belo Horizonte, Minas Gerais state, Brazil.

The project was submitted to the Federal University of Minas Gerais Ethics Committee on the Use of Animals (CEUA), and it was approved under Protocol no. 371/2014. Forty-eight dogs aged 2-5 years, from either a private clinic (VetMaster, Belo Horizonte) or the Zoonoses Control Center of Belo Horizonte (CCZ-BH), were used in the present study. These animals were sent for a complete general and orthopedic clinical examination. In addition, a blood sample was submitted for an immunochromatographic test for the diagnosis of ehrlichiosis (Alere Erliquiose Ac Test Kit). Animals with orthopedic alterations, who were positive for ehrlichiosis, or with clinical alterations suggestive of any other infectious diseases were excluded from the study.

The animals were separated into three groups. The control group (G1) consisted of 12 apparently healthy dogs that were serologically negative for CVL in commercial IFAT and ELISA tests. The other 36 dogs were serologically positive for
CVL in the ELISA and IFAT tests, with titers equal or higher than $1 / 80$. These animals were classified into two groups according to the clinical signs observed during the clinical examination as previously described by SOLANO-GALLEGO et al. (2011). Group 2 (G2) included 18 animals in stage II of the disease (moderate leishmaniosis), with the presence of at least one of these clinical signs: lymphadenomegaly, papular dermatitis, onychogrifosis, skin ulcerations, weight loss and epistaxis. Group 3 (G3) included 18 animals in stage III (severe disease) with the presence of the clinical signs described in G2 and at least one of these additional clinical signs: vasculitis, arthritis, uveitis, and glomerulonephritis.

Using a $3 \mathrm{ml}$ syringe and a $25 \times 7$ needle, 500-700 $\mu \mathrm{L}$ of $\mathrm{SF}$ from the tarsal joints was collected after trichotomy and antiseptic wash with chlorhexidine at $2 \%$. The tarsus was the site of choice for the collection of SF because being a distal joint, it is more easily affected by parasitic arthritis due to hemodynamic factors (SILVA, 2009). The collected specimen was stored in microtubes with and without EDTA at $4^{\circ} \mathrm{C}$. The SF analysis included the direct investigation of intra and extracellular protozoa using a microscope under the immersion objective.

All animals from G1 were negative in the parasitological analysis of SF (Table 1). Among the 36 symptomatic animals investigated (18 from G2 and 18 from G3), 22 (61.1\%) tested positive for Leishmania sp. in the SF. These results are in accordance with previous studies that reported a sensitivity between $23 \%$ and $64 \%$ when using SF to diagnose CVL (SILVA, 2009). Interestingly, Fisher's exact test revealed that dogs in stage 3 of the disease are more likely to test positive for Leishmania sp. in analysis of the SF (Table 1; $\mathrm{p}=0.0437)$. Together, these results suggested that the parasitological analysis of SF is not a good option as a single test to diagnose CVL due to its low negative predictive value. However, the test seems suitable as an auxiliary tool in the parasitological diagnosis of CVL in symptomatic dogs.

Notably, amastigotes in neutrophil and macrophage cytoplasm were the most common form observed in the present study and were detected in 16 CVL-positive animals. Free amastigotes were also reported in combination with amastigotes in the neutrophil and macrophage cytoplasm in two dogs, both in group 3 (severe disease). This finding is in accordance with that of previous studies that reported Leishmania sp. amastigotes in the cytoplasm of mononuclear and neutrophil cells as the most common form observed during parasitological evaluations of 
Table 1 - Number of dogs positive for Leishmania sp. in the synovial fluid of the control group (G1) and in dogs with CVL at stages II (G2) and III (G3).

\begin{tabular}{|c|c|c|c|c|c|c|}
\hline \multirow{2}{*}{ Detection } & \multicolumn{2}{|c|}{$\mathrm{G} 1(\mathrm{n}=12)$} & \multicolumn{2}{|c|}{ G2 (n=18) } & \multicolumn{2}{|c|}{ G3 $(n=18)$} \\
\hline & $\mathrm{n}$ & $\%$ & $\mathrm{n}$ & $\%$ & $\mathrm{n}$ & $\%$ \\
\hline Positive & 0 & 0 & 6 & 33.3 & 16 & 88.9 \\
\hline
\end{tabular}

1 dogs with CVL (SPRENG, 1993; BURACCO et al., 2 1997; MCCONKEY et al., 2002).

3 According to NOLI \& 4 SARIDOMICHELAKIS (2014), cytology is a 5 powerful diagnostic tool because of its low cost, 6 minimal requirements for technical equipment, fast 7 availability of test results, and absolute specificity. On 8 the contrary, most studies using cytology methods did 9 not report the clinical status of the dogs tested; hence, 10 the influence of the disease stage in this technique 11 remains unknown (SARIDOMICHELAKIS et al., 12 2005; SARIDOMICHELAKIS，2009; NOLI \& 13 SARIDOMICHELAKIS, 2014). In this context, 14 the present study confirms that the parasitological 15 analysis of SF is a method with a high positive 16 predictive value to diagnose $\mathrm{CVL}$, and it is a good 17 option to easily confirm the disease in symptomatic 18 dogs in clinics or veterinary hospitals.

19 In conclusion, this is the first study 20 evaluating the association of the clinical stage of 21 CVL with the likelihood of positive results in the 22 parasitological analysis of SF. The method presented 23 here demonstrated efficacy for the diagnosis of CVL 24 in symptomatic dogs, mainly in animals presenting 25 severe clinical conditions. Because the method is

\section{DECLARATIO
INTERESTS}

The authors declare no conflict of interest. The founding sponsors had no role in the design of the study; in the collection, analyses, or interpretation of data; in the writing of the manuscript, and in the decision to publish the results.

\section{AUTHORS' CONTRIBUTIONS}

All authors contributed equally for the conception and writing of the manuscript. All authors critically revised the manuscript and approved of the final version.

\section{REFERENCES}

ALVAR, J., et al. Canine leishmaniasis. Advances in Parasitology, Londres, v.57, p.1-88, 2004. Available from: <https://www.ncbi. nlm.nih.gov/pubmed/15504537>. Accessed: Nov. 20, 2018. doi: 10.1016/S0065-308X(04)57001-X.

BURACCO, P.; et al. Osteomyelitis and arthrosynovitis associated with Leishmania donovani infection in dog. England. Small Anim. Pract., v.38, n.1, p.29-30, 1997. Available from: <https://www. ncbi.nlm.nih.gov/pubmed/9121132>. Accessed: Nov. 20, 2018. doi: 10.1111/j.1748-5827.1997.tb02983.x.

LOPES, E.G et al. Serological and molecular diagnostic tests for canine visceral leishmaniasis in Brazilian endemic area: one out of five seronegative dogs are infected. Epidemiol Infect, 145(12), 2017. Available from: <https://www.ncbi.nlm.nih.gov/ pubmed/28726597>. Accessed: Nov. 20, 2018. doi: 10.1017/ S0950268817001443.

MCCONKEY, E. S. et al. Leishmanial polyarthritis in a dog. Can. Vet. J., v. 43, n. 8, p. 607-609, 2002. Rev Soc Bras Med Trop. 2014 Jan-Feb; 47(1):105-7. Available from: <https://www. ncbi.nlm.nih.gov/pmc/articles/PMC339396/>. Accessed: Nov. 20, 2018. doi: 10.1590/0037-8682-1723-2013.

MENDONÇA, I.L.; BATISTA, J.F. The performance of serological tests for Leishmania infantum infection screening in dogs depends on the prevalence of disease. Rev Inst Med Trop São Paulo. 59: e39, 2017. Available from: <https://www.ncbi.nlm.nih.gov/ pubmed/28591267>. Accessed: Nov. 20, 2018. doi: 10.1590/ S1678-9946201759039.

MONTEIRO, E. M. et al. Leishmaniose visceral: estudo de flebotomíneos e infecção canina em Montes Claros, Minas Gerais. Revista da Sociedade Brasileira de Medicina Tropical, v.2, n.38, p.147-152, 2005. Available from: <http://dx.doi.org/10.1590/ S0037-86822005000200004>. Accessed: Nov. 20, 2018. doi: $10.1590 / \mathrm{S} 0037-86822005000200004$.

NOLI, C.; SARIDOMICHELAKIS, M.N. An update on the diagnosis and treatment of canine leishmaniosis caused by Leishmania infantum (syn. L.chagasi). Vet J. 2014 Dec; 202(3):425-35. Available from: <https://www.ncbi.nlm.nih.gov/ pubmed/25266647>. Accessed: Nov. 20, 2018. doi: 10.1016/j. tvj1.2014.09.002.

RIBEIRO, R. R, et al. Canine Leishmaniasis: An Overview of the Current Status and Strategies for Control. Biomed Res Int. 2018, Mar. 29; 2018: 3296893. Available from: <https://www.ncbi. nlm.nih.gov/pubmed/29789784>. Accessed: Nov. 20, 2008. doi: $10.1155 / 2018 / 3296893$.

SARIDOMICHELAKIS, M.N. Advances in the pathogenesis of canine leishmaniosis: epidemiologic and diagnostic implications. Vet dermatol. n.20, p.471-489, 2009. Available from: < https://

Ciência Rural, v.49, n.5, 2019. 
1 www.ncbi.nlm.nih.gov/pubmed/20178485>. Accessed: Nov. 20, 2018. doi: 10.1111/j.1365-3164.2009.00823.x.

SARIDOMICHELAKIS, M.N.; et al. Evaluation of lymph node and bone marrow cytology in the diagnosis of canine leishmaniasis (Leishmania infantum) in symptomatic and asymptomatic dogs. Am J Trop Med Hyg. 2005 Jul; 73(1):82-6. Available from: $<$ https://www.ncbi.nlm.nih.gov/pubmed/16014839>. Accessed: Nov. 20, 2018.

SILVA, F. L. et al. Venereal transmission of canine visceral leishmaniasis. Vet. Parasitol. v.1-2, n.106, p.55-59, 2009. Available from: <https://www.ncbi.nlm.nih.gov/pubmed/19046812>. Accessed: Nov. 20, 2018. doi: 10.1016/j.vetpar.2008.10.079.

SILVA, M. N. G. et al. Parasitological analysis of synovial fluid from dogs naturally infected with Leishmania sp. Ciência Rural, v.44, n.7, p.1236-1239, Santa Maria, 2014. Available from: $<$ http:// dx.doi.org/10.1590/0103-8478cr20130965>. Accessed: Nov. 20, 2018. doi: 10.1590/0103-8478cr20130965.

SOLANO-GALLEGO, L. et al. Directions for the diagnosis, clinical staging, treatment and prevention of canine leishmaniosis. Veterinary Parasitology, n.28, v.165(1-2), p.1-18, 2009. Available from: $<$ https:// www.ncbi.nlm.nih.gov/pubmed/19559536>. Accessed: Nov. 20, 2018. doi: 10.1016/j.vetpar.2009.05.022.
SOLANO-GALLEGO, L. et al. Leishvet guidelines for the pratical management of canine leishmaniosis. Parasites \& vectors, v.4, n.1, p.86, 2011. Available from: <https://parasitesandvectors. biomedcentral.com/articles/10.1186/1756-3305-4-86>. Accessed: Nov. 20, 2018.

SPRENG, D., Leishmanial polyarthritis in two dogs. Journal Small Animal Practice. v.34, p.559-563, 1993. Available from: $<$ https://doi.org/10.1111/j.1748-5827.1993.tb03548.x>. Accessed: Nov. 20, 2018. doi: 10.1111/j.1748-5827.1993.tb03548.x.

VILAS, V.J.; et al. Visceral leishmaniasis: a One Health approach. Vet Rec. 175: 42-4, 2014. Available from: <https://www.ncbi. nlm.nih.gov/pubmed/25013197>. Accessed: Nov. 20, 2018. doi: $10.1136 / v r . g 4378$

WHO (2010) Control of the leishmaniasis: report of a meeting of the WhO expert Committee on the Control of Leishmaniases. in WhO Technical Report series, 186. Available from: $<$ https://apps.who.int/iris/handle/10665/44412>. Accessed: Nov. 20, 2018.

WHO (2014) Leishmaniasis: A Global Brief on Vector Borne Diseases. Available from: <http://apps.who.int/iris/ bitstream/10665/111008/1/WhO_DCO_WhD_2014.1_eng.pdf.>. Accessed: Nov. 20, 2018. 